\title{
Sedimentological Characterization of Alluvial Gold Deposits of Betrare-Oya and Its Surroundings (Cameroon Eastern Region)
}

\author{
Daniel Mackaire Eloung Nna ${ }^{1}{ }^{*}$, Paul Desiré Ndjigui ${ }^{1}$, Joseph Quentin Yene Atangana ${ }^{1}$, \\ Alexis Jacob Nyangono Abolo² ${ }^{2}$ Constantin Maurice Ndongue ${ }^{1}$ \\ ${ }^{1}$ Department of Earth Sciences, University of Yaounde I-Cameroon, Yaounde, Cameroon \\ ${ }^{2}$ Faculty of Mines and Petroleum Industries, University of Maroua-Cameroon, Maroua, Cameroon \\ Email: *eloungnnadm2020@gmail.com
}

How to cite this paper: Nna, D.M.E., Ndjigui, P.D., Atangana, J.Q.Y., Abolo, A.J.N. and Ndongue, C.M. (2020) Sedimentological Characterization of Alluvial Gold Deposits of Betrare-Oya and Its Surroundings (Cameroon Eastern Region). International Journal of Geosciences, 11, 783-799.

https://doi.org/10.4236/ijg.2020.1112040

Received: August 30, 2020

Accepted: December 21, 2020

Published: December 24, 2020

Copyright $\odot 2020$ by author(s) and Scientific Research Publishing Inc. This work is licensed under the Creative Commons Attribution International License (CC BY 4.0).

http://creativecommons.org/licenses/by/4.0/ (c) (i) Open Access

\begin{abstract}
Sedimentological methods such as granulometry, morphoscopy and heavy minerals analysis have been carried out to characterize alluvial gold deposits of Betare-Oya and its surroundings, with the aim to determine their origin and conditions in which they are formed and also to determine the mineralogical content of these deposits, their nature and distribution. It came out from this study the following: The alluvial deposits studied are sand, constituting of coarse fraction (grains), medium grains in abundant and fine grains. The average values of sorting index (S0) and coefficient of asymmetry (A) are respectively 2.53 and 0.73 . These values indicate that the sand is poorly arranged and poorly sorted with a better classification or arrangement in the coarse fraction (grains). These are sediments that are deposited together by high competent currents. It would therefore probably be torrential deposits and or streams from short transport. Unused grains are dominating (80.5\%) which translate a proximal source of the sediments. So it would be probably from the dismantling of the surrounding landforms. The heavy minerals studied revealed the presence of the following minerals; zircon, gold, sphene, green hornblende, tourmaline, rutile, augite, hypersthene, sillimanite, glaucophane, biotite, staurotide, and the opaque. These minerals belong to the cortege of plutonic and metamorphic rocks from a single proximal distributing province.
\end{abstract}

\section{Keywords}

Betare-Oya and Its Surroundings, Alluvial Gold Deposits, Granulometry, Morphoscopy, Heavy Minerals, Polished Sections 


\section{Introduction}

Gold remains one of the world's economy strategic resource; its exploration, therefore, remains a permanent and decisive activity. In Cameroon, the intensive exploitation of alluvial gold has led to an exhaustion of mineralized deposits in some basins of production. This is the case of the zone of Betare-Oya in the East Region of Cameroon. So it's crucial for the research of new auriferous indices and most importantly their primary source so as to maintain the activity and increase production for a better contribution of the natural resource to the Gross Domestic Product(GDP) of the country. The characterization of alluvial deposits by the sedimentological methods such as; particle size, morphoscopy and the study of the heavy minerals constitute an approach which adheres or concurs to the exploration of gold. It will lead to the understanding of the sedimentary dynamics responsible for the formation of these deposits and also to know the origin of the mineralization and their distribution.

\section{Geological Setting}

The study area, Betare-Oya is found in the East Region of Cameroon. The study area is characterized by two (02) main hydrographic basins namely, Lom basin in the North West and Kadei basin in the South East (Figure 1).

The geological context is that of the Pan-African base of the Cameroon center. The geology of the Betare-Oya area is dominated by volcano-sedimentary rocks of Neoproterozoic in the Lommetamorphise group [1]. In fact, the Lom basin which is the greatest hydrological collector of the area is mainly composed of

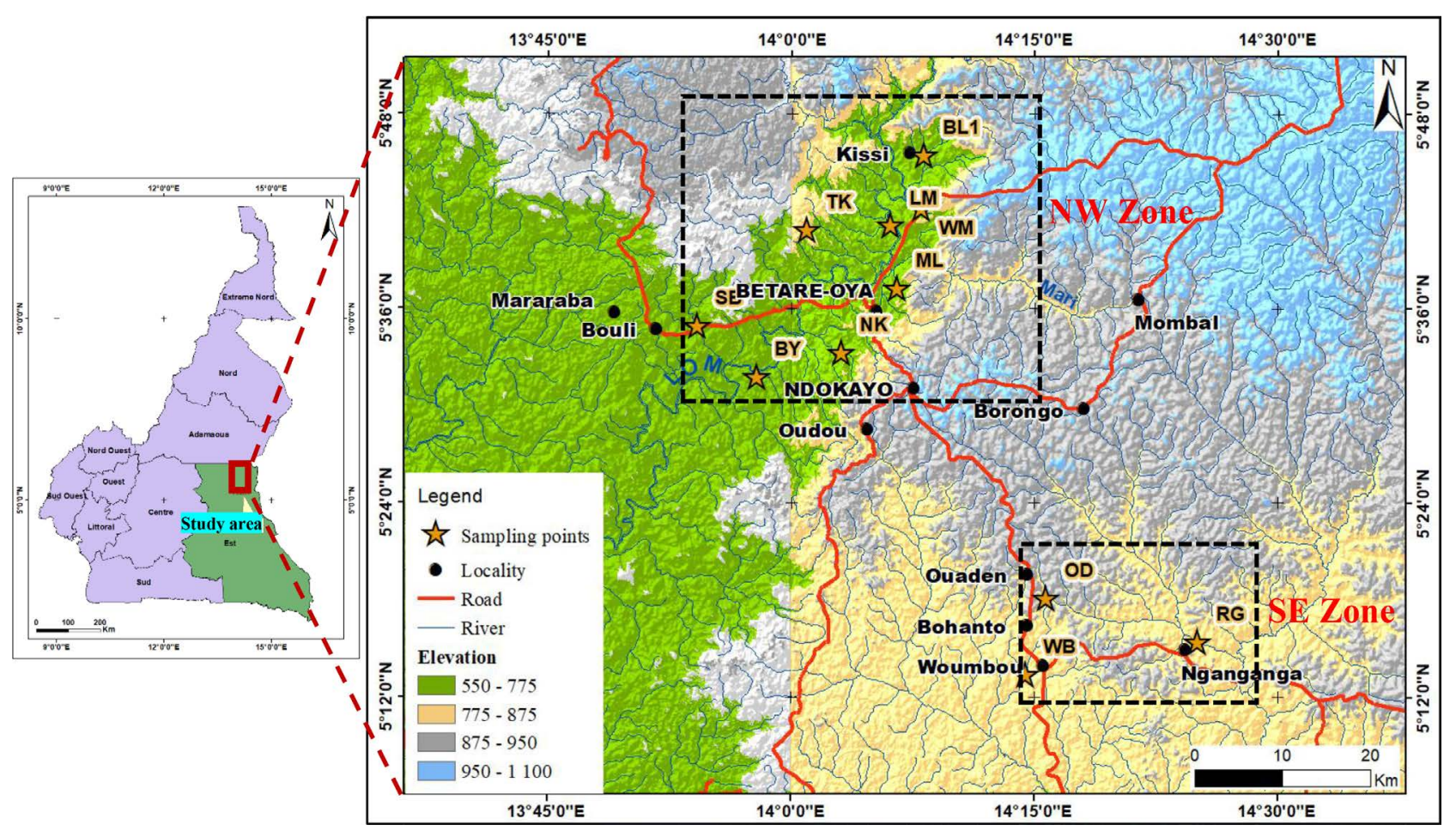

Figure 1. Location map of Eastern region of Cameroon and location map of the study area, with sampling points location. 
metasedimentary rocks grouped into two main structural and sedimentary units. These units include the monocyclic unit which is composed of the volcanoclastic materials of the Lom series, orthogenesis, quartzites and the polygenic conglomerates of Mali [2] [3], the metamorphosed green schist associated with the graben. The polycyclic unit as for it includes the Mica schists, gneisses of the Lom bridge and the myloniteschloritoides-staurolites linked to the structures in horst form [3] [4] (Figure 2). These mylonites are the main characteristics of the presence of the Sanaga Fault (SF) in the Region [2]. These different units are crossed by quartz veins and the Pan-African granitoids (granites, monzoniteetc.) [1] [4]. Structurally, the schists are well folded with an orientation of NE-SW linked to the shear zone system. The alluvial and eluvial deposits are abundant and hence concentrate mineralization [1].

The geology of the Ngoura zone is associated with that of Batouri as described by [5]. In fact, these zones are formed of three (03) types of granitic intrusions in the metamorphic host namely;

- Ancient syntectonic granites with often heterogeneous structures and with a composition often oriented or even gneissic and whose contours are consistent with the host formation.

- Late homogeneous syntectonic granites of compositions close to the previous ones;

- Discordant post-tectonic granites, very homogeneous and more alkaline in composition than the previous two.

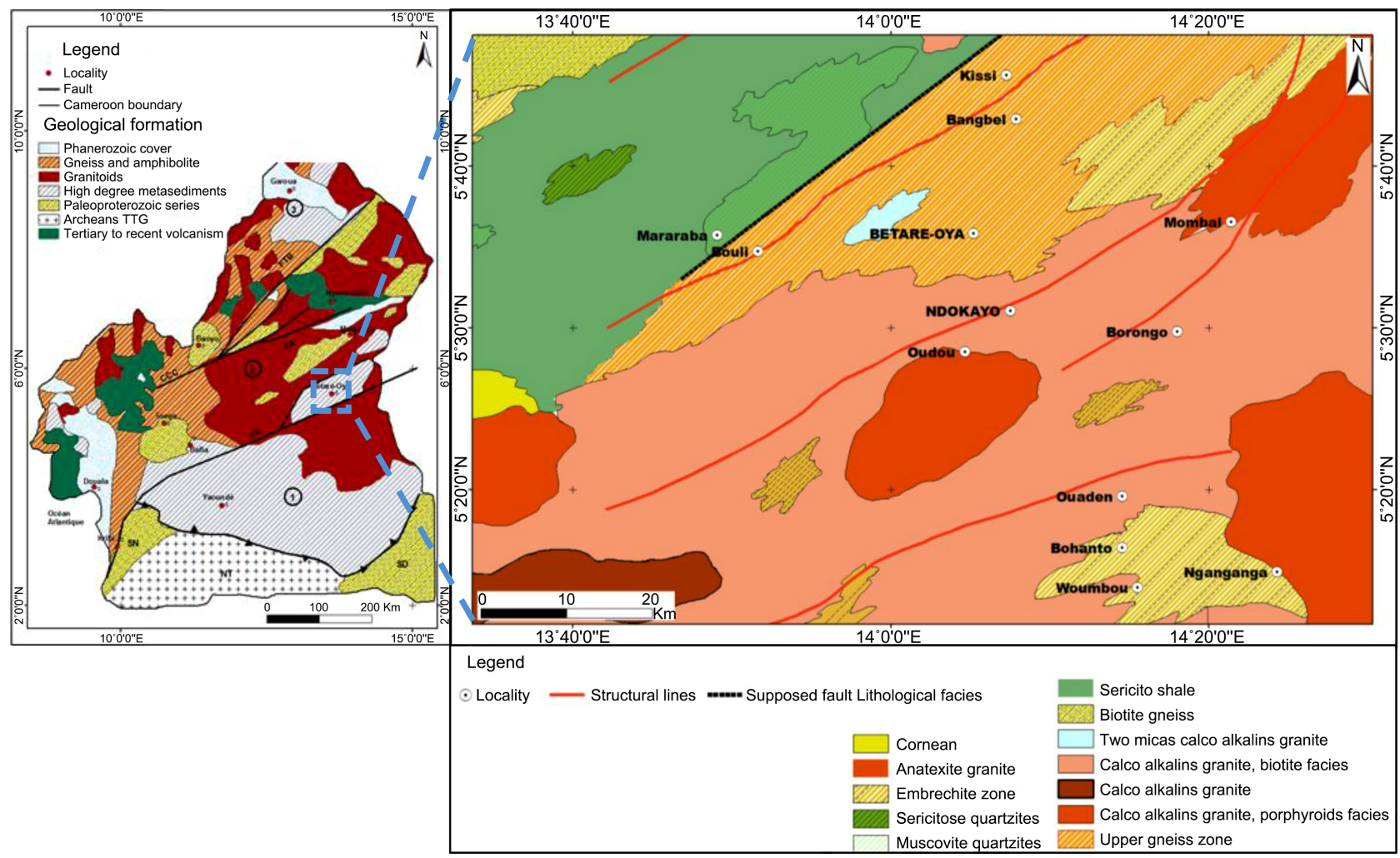

Figure 2. Generalized geological map of Cameroon and geological map of the study area. 
Moreover, we note the presence of primary gold mineralization linked to siliceous appearances of vein appearance in shales and quartzites or then in the disseminated form in the plutonic massifs [5].

\section{Methodology of Investigation}

\subsection{Sampling}

The alluvial deposits studied are surface sediments of the rivers distributed in the 11 sectors which are: Lom sector (LM), Mali (ML), Nakoyo (NY), Bangbel (BL), Sarambi (SB), Boyo (BY), Tourake (TK), Wantamo (WM), in the North West zone of the study area and Woumbou (WB), Ouaden (OD) and Rigue (RG) in the South-East zone (Figure 1).

A total of 11 samples corresponding to the 11 sectors were taken from the flats (right bank and left bank) and from the beds of the rivers between 1 and $8 \mathrm{~m}$ of depth; these are gravel levels. After washing the samples with the use of a washed pan, these samples were the subject of particle size, morphoscopic and mineralogical analyses.

\subsection{Study of Particle Size}

The sediments were sieved by agitation according to the conventional procedure [6], on an AFNOR column of 9 sieves with decreasing mesh, from top to bottom having the following meshes; $4,2,0.5,0.4,0.315,0.2,0.1,0.08$, and $0.05 \mathrm{~mm}$. The sieving process was carried out for 15 minutes continuously with a constant amplitude of agitation. The rejects collected in each sieve were weighed on an electronic balance with a precision of $0.01 \mathrm{~g}$. According to the Folk and Ward method [7], these data makes it possible to plot histograms and cumulative curves, to calculate the particle size parameters such as the Mode (Mo), Median (Md) and the quartiles (Q1, Q2 and Q3) and the sedimentological parameters such asymmetry coefficient noted A (or Skewness noted Sk). These parameters make it possible to characterize the feeling and the processes of transport and sedimentation [8].

These parameters also make it possible to define the mode of transport of the sediments as well as the of deposit midium resulting from the diagrams of Visher [9] and Moiola and Weiser [10]. In fact, numerous studies have shown that the Md-So diagrams applied to sands, permit to determine their deposit environment [11] [12].

\subsection{Morphoscopic Study}

The morphoscopic analysis of the quartz grains was carried out with a binocular microscope at a magnification of 40 . The counting was carried out on 100 grains per sample. The objective was to trace their conditions of transport. The surface appearance and the shape of a quartz grain closely linked to their environments and modes of transport [13], thus proposes the classification of all quartz grains into three (03) categories; the unused corresponding to sand closer to its source 
of materials, the shiny foam which characterizes an aquatic transport and the dull circles which indicates transport by wind.

\subsection{Mineralogical Study}

\subsubsection{Heavy Minerals}

Heavy minerals act as markers which provide information on the origin of rocks and the conditions of transport [14] [15]. In order to make the identification of heavy minerals, the samples taken underwent physical treatment mainly by the quartering and sieving on approximately $20 \mathrm{~g}$ of the collected samples. The particles size cuts adopted in this work and recommended by Berthois and Lucas [16] are distinct into three (03) fractions; 1) $60 \mu \mathrm{m}-250 \mu \mathrm{m}$; 2) $250 \mu \mathrm{m}-315$ $\mu \mathrm{m}$; 3) $315 \mu \mathrm{m}-500 \mu \mathrm{m}$. These different fractions will undergo treatment with hydrochloric acid (10\%) for 15 minutes for the removal of cements and lime tests while organic debris are eliminated with oxygenated water $\left(\mathrm{H}_{2} \mathrm{O}_{2}\right)$ for 10 minutes. The densimetric separation or extraction of heavy minerals is done by immersion of the minerals in bromoform $\left(\mathrm{CHBr}_{3}\right)$ which is a liquid of density equal to 2.89; minerals with a lower density than that of the bromoform will float on the surface and those with a high density are deposited at the bottom of the separating funnel [17]. Once obtained, the minerals are mounted between thin sections and lamella on a plat of Malassez using Canada balsam. Thus, when the slide is prepared, it is then ready for microscopic examination. Minerals are identified using a polarizing microscope.

\subsubsection{Polished Sections}

Preparing polished sections is similar to other materials preparation. It therefore includes cutting in reduced dimensions as well as bonding to glass slide, etc. the preparation follows the following steps or stages: After consolidation of the sample by the means of a polymerizable resin, one proceeds to the coating in order to obtain a suitable geometry or to protect the sample. Then a grinding/lappingoperation is carried out in order to eliminate surface damage so as to obtain a flat surface and to prepare it for polishing. And finally, we proceed to polish the surface, which reveals the structures of the sample and obtain a reflecting surface [18] [19]. The sample is thus ready for observation under an optical microscope by reflection.

\section{Results and Discussions}

\subsection{Particle Size Data}

The results obtained after sieving (Table 1) make it possible to construct graphs (histograms and cumulative curves) and to calculate the main particle size parameters which are Mode (Mo), Median (Md) and quartiles (Q1, Q2 and Q3), and the sedimentological parameters such as the sorting index (S0), the Krumbein index (QdØ) and the asymmetry coefficient noted A (Skewness noted Sk). All these parameters are listed in Table 2. 


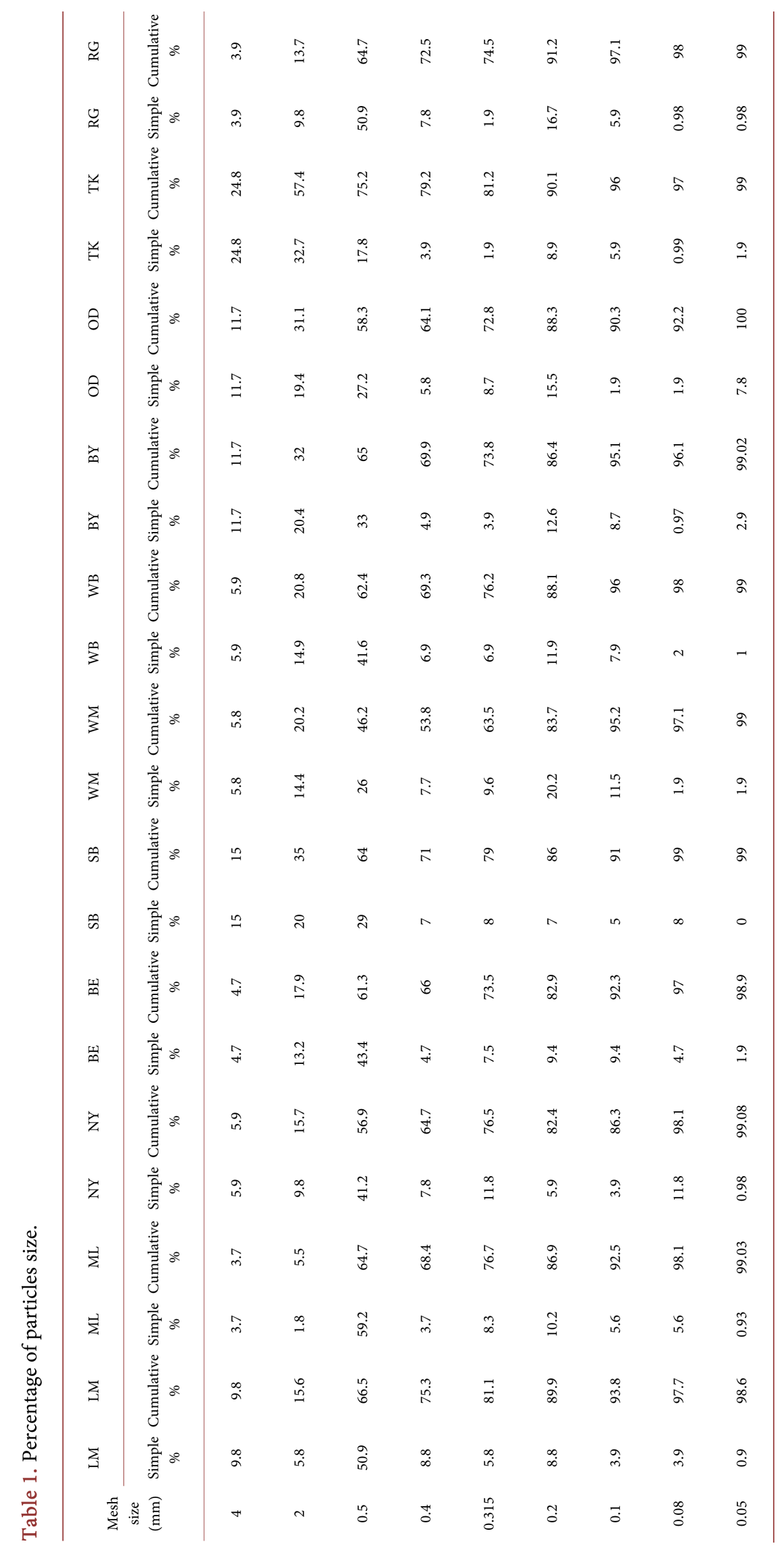


Table 2. Particle size and sedimentological parameters.

\begin{tabular}{|c|c|c|c|c|c|c|c|c|c|c|c|c|}
\hline \multicolumn{13}{|c|}{ Samples } \\
\hline Parameters & LM & ML & NY & $\mathrm{BL}$ & SB & WM & WB & BY & OD & TK & RG & $\begin{array}{c}\text { Average } \\
\text { values }\end{array}$ \\
\hline \multirow{3}{*}{ Modes (mm) } & 4 & 0.5 & 0.5 & 0.5 & 0.5 & 0.5 & 0.5 & 0.5 & 2 & 2 & 0.5 & I \\
\hline & 05 & 0.2 & 0.32 & 0.2 & 0.32 & 0.2 & 0.2 & 0.2 & 0.2 & 0.2 & 0.2 & I \\
\hline & 0.2 & l & 0.08 & & 0.08 & 1 & 1 & & 0.1 & 1 & 1 & l \\
\hline $\mathrm{Q} 1=\mathrm{Q} 25$ & 1.7 & 1.5 & 1.6 & 1.8 & 3 & 1.7 & 1.9 & 2.7 & 2.6 & 4 & 1.7 & 2.2 \\
\hline $\mathrm{Q} 2=\mathrm{Q} 50=\mathrm{Md}$ & 1 & 0.9 & 0.75 & 0.9 & 1.22 & 0.5 & 1 & 1.2 & 1 & 2.5 & 0.9 & 1.06 \\
\hline $\mathrm{Q} 3=\mathrm{Q} 75$ & 0.4 & 0.3 & 0.33 & 0.3 & 0.36 & 0.3 & 0.3 & 0.3 & 0.3 & 0.5 & 0.3 & 0.34 \\
\hline So & 2.1 & 2.1 & 2.24 & 2.4 & 2.89 & 2.6 & 2.4 & 3 & 3 & 2.8 & 2.3 & 2.53 \\
\hline QdØ & 1.5 & 1.4 & 1.5 & 1.6 & 2.82 & 1.6 & 1.7 & 2.5 & 2.5 & 3.7 & 1.5 & 2.03 \\
\hline A & 0.7 & 0.7 & 0.97 & 0.7 & 0.73 & 2.1 & 0.7 & 0.6 & 0.86 & 0.4 & 0.6 & 0.73 \\
\hline
\end{tabular}

- The mode of the samples studied varies between 4 and $0.05 \mathrm{~mm}$ respectively for the LM and OD samples, with a recurrence of modes 0.5 and $0.2 \mathrm{~mm}$. These plurimodial samples on a whole correspond to sediments which are less well classified and not yet sorted; these would be sediments which come from various sources [20].

- The median (Md) shows values between 0.45 and 2.45 for an average of 1.06. The highest median is from the TK sample while the reliable is from the WM sample. The vast majority of the studied samples present values of medians which are not close to the values of the modes with the exception of the WM sample (value of median and mode are near), which translates badly classified sediments joined together.

- The sorting index (S0) displays values that range between 2.07 and 2.99 respectively in the LM and BY samples. The average S0 is 2.53 for all the samples studied. According to Table Y, 06 samples (LM, ML, NY, BL, WB, and RG) have S0 values less than 2.5 , which indicates a well-classified sediments of fluvial origin; while S0 between 2.5 and 3.5 correspond to fairly well-classified sediments. The average of $\mathrm{S} 0=2.53$ corresponds to sediments which are fairly well classified overall.

- The Krumbein index (Qd $\varnothing$ ) shows values between 1.5 and 3.73 respectively in the NY and TK samples. The average value across all samples is 2.03. It is known that, sediment is well classified if its value tends towards zero (0); however, it turns out that the QdØ values obtained in the samples studied are not close to zero (0), therefore, we are in the presence of poorly classified sediments.

- Asymmetry (A) or Skweness (Sk) values are between 0.35 and 2.12, values obtained in the TK and WM samples respectively; for an average of 0.73 on all the samples studied. The asymmetrical coefficient which displays an aver- 
age value of 0.73 , that is to say less than 1 , reflects a maximum classification on the side of coarse grains; which would correspond to poorly classified torrential sediments.

- The frequency curves obtained, on the other hand, shows a slight irregular slope (Figure 3), which corresponds to poorly classified sediments. The analyzed samples show histograms that are on the whole multimodal (bimodal to trimodal) (Figure 4) with two frequent modes namely 0.5 and 0.2 . This multimodality of the samples would correspond to deposits from a short course, by irregular currents. These are poorly sorted sediments.

The parameters S0 and Qd $\varnothing$ are relatively similar in the NW and SEzones. However, although the mean values of the asymmetry index are less than 1 , it appears that the asymmetry to NW has a value that is closer to 1 unlike that of the SE zone. This implies that the sediments in the NW (Lom basin) are more evolved than those in the SE (Kadei basin) characterized by coarser sediments, which therefore belong to the torrential type.

The Md-S0 diagram resulting from the granulometric parameters of the sand samples make it possible to determine their depositional environment. The Md-S0 diagram obtained during this work reveals that the sediments studied are derived mainly from the river domain (Figure 5). In view of the above, it merges that, the alluvial deposits studied belong to a fluvial type deposition environment.

\subsection{Morphoscopic Data}

The study was carried out at the laboratory of the Small-scale Mining Support and Promotion Framework Unit (CAPAM) in Yaounde, which made it possible to determine the percentage of unused grains, shiny blunt grains and round-mast grains contained in the 11 samples analyzed. The results obtained after observations are recorded in Table 3.

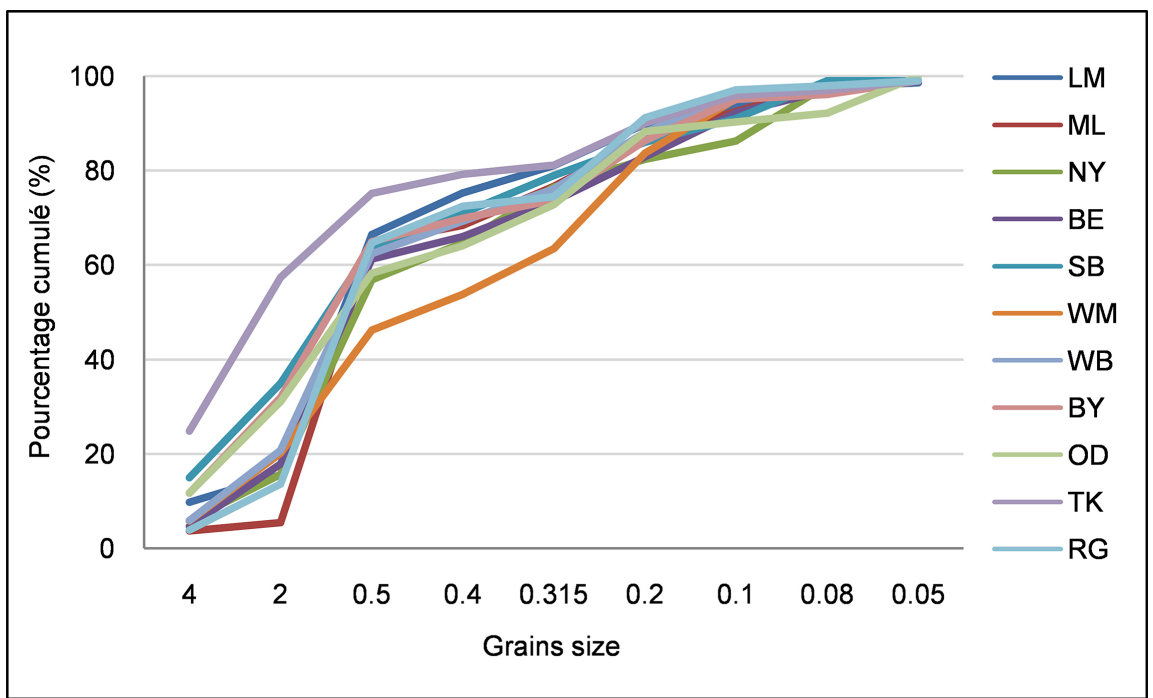

Figure 3. Cumulative granulometrics curves of the samples. 

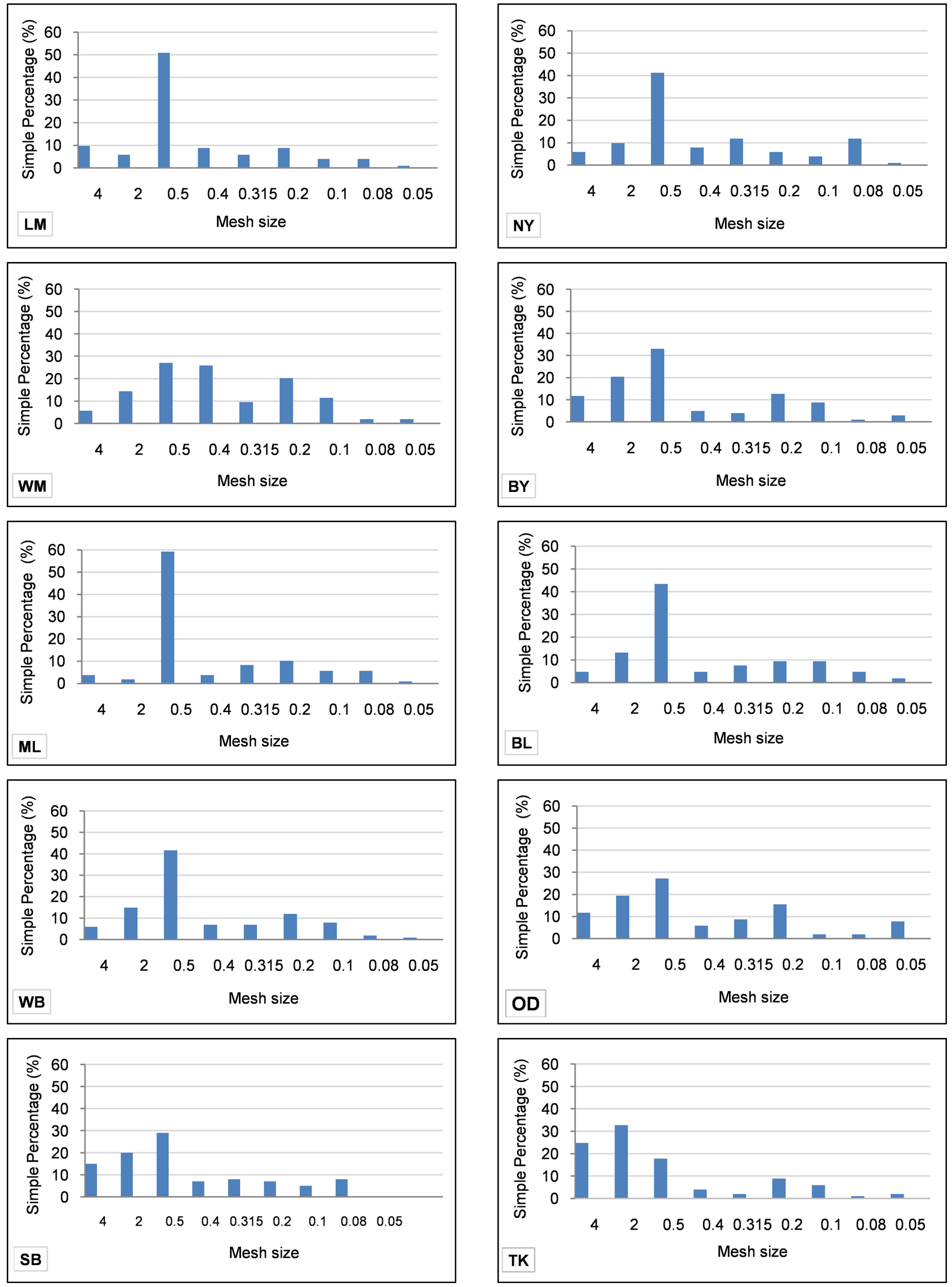


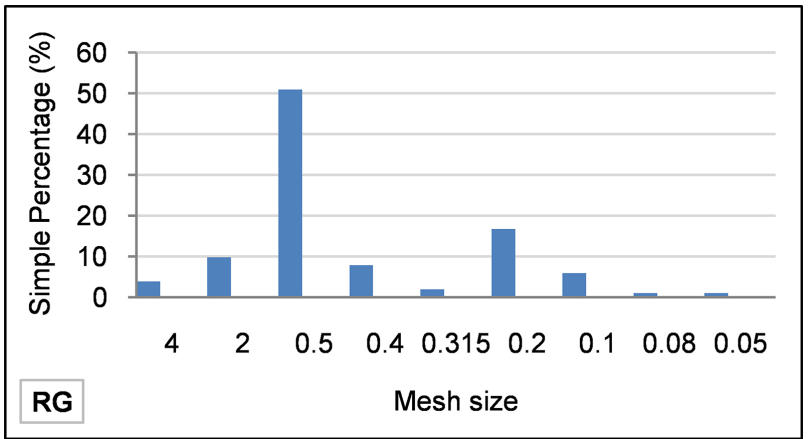

Figure 4. Histograms of the samples LM (Lom sector), WM (Wantamo area), ML (Mali sector), WB (Woumbou sector), SB (Sarambi sector), TK (Tourake sector), NY (Nakoyo sector), BY (Boyo sector), BL (Bangbel sector), OD (Ouaden sector), and RG (Rigue sector).

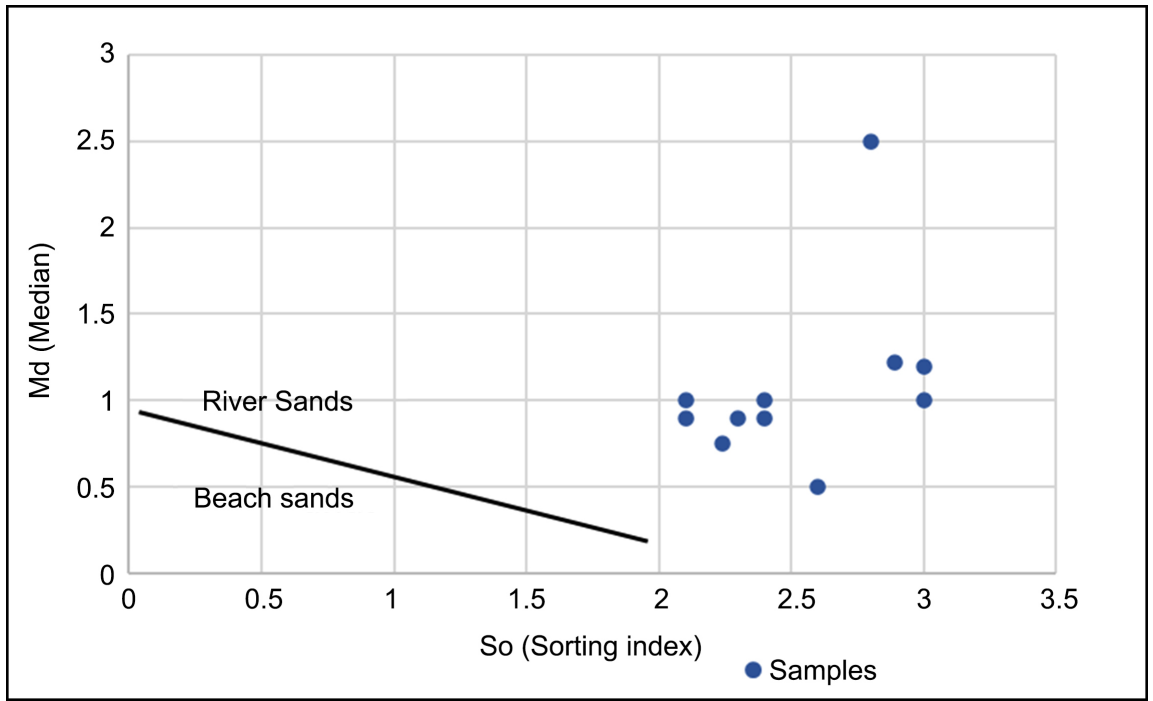

Figure 5. Diagram Md-So of the study area's sediments.

Table 3. Percentage of differents typesof grain.

\begin{tabular}{ccccc}
\hline Sectors & Samples & Unused (\%) & Shiny blunt (\%) & Round mast (\%) \\
\hline Lom & LM & 87 & 12 & 1 \\
Mali & ML & 78 & 21 & 1 \\
Nakoyo & NY & 80 & 20 & 0 \\
Bangbel & BL & 81 & 18 & 1 \\
Sarambi & SB & 85 & 13 & 1 \\
Wantamo & WM & 75 & 23 & 2 \\
Woumbou & WB & 81 & 18 & 1 \\
Boyo & BY & 82 & 17 & 1 \\
Ouanden & OD & 78 & 21 & 1 \\
Touraké & TK & 83 & 16 & 1 \\
Rigué & RG & 76 & 23 & 1 \\
\hline
\end{tabular}


The data obtained make it possible to construct the histogram of Figure 6. The following are from this analysis: The unused grains are between $75 \%$ and $87 \%$, respectively in the WM and LM samples, for an average of $80.54 \%$ for all the samples analyzed.

The shiny blunt grains are between $12 \%$ and $23 \%$ respectively in the samples LM and WM and RG respectively. The average for this type of grain is $18.36 \%$. The round mast grains, for their part show percentages which vary between 0 and $2 \%$ obtained respectively in the samples NY and WM; and an average of $1 \%$.

\subsection{Mineralogical Data}

\subsubsection{Microscopy of Heavy Minerals}

The polarizing microscope observation of thin sections made it possible to distinguish mainly the following heavy minerals; Opaque, Zircon, green hornblende, tourmaline, sillimanite, biotite, brown hornblende, rutile, garnet, sphene, staurotide, muscovite, hypersthene and glaucophane (Table 4).

The percentage or average content of these different heavy minerals obtained in the samples is expressed in the form of a pie chart (Figure 7).

- Opaque is the first mineral species in terms of representation $(33.6 \%$ on average). They are dark minerals of a more or less rounded shape whose light could not pass through.

- Zircon is present in all the samples studied; their content varies from $10 \%$ to $25 \%$ with an average of $12 \%$. They are more abundant in samples from the SE zone, where their content varies between $28 \%$ and $32 \%$. In the NW zone, the content varies between $5 \%$ and $10 \%$.

- Green hornblende is also present in all samples; their proportion varies between $6 \%$ and $18 \%$, for an average of $12 \%$. The highest proportion (18\%) is recorded in the WM sample from the NW zone.

- Brown tourmaline comes in slightly elongated rods, striated longitudinally. It is brown in PLNA. Its percentage of representation varies between $4 \%$ and $12 \%$, an average of $8 \%$.

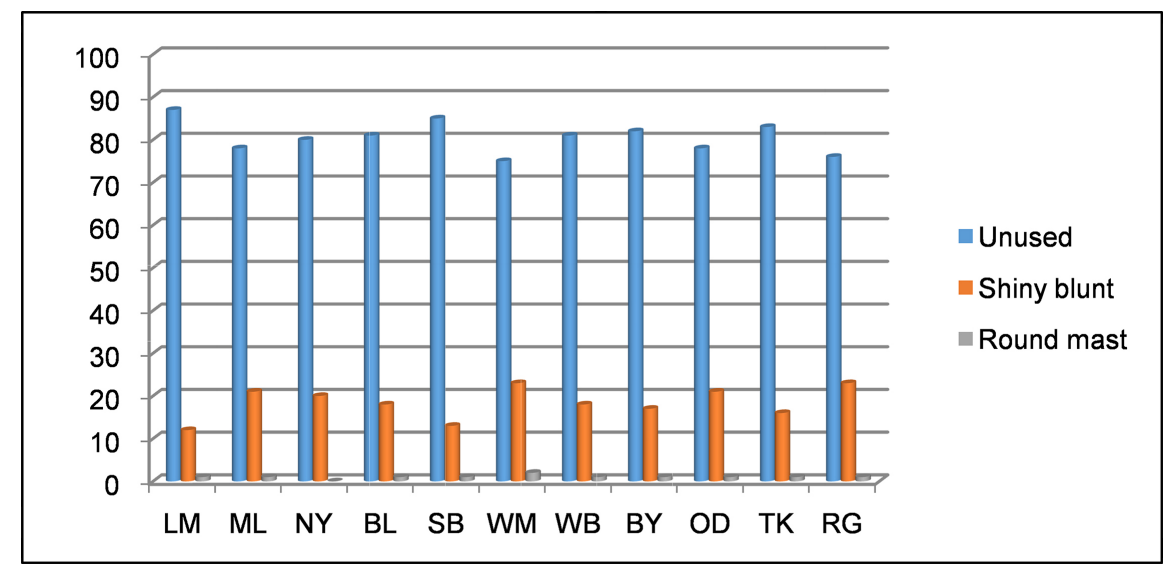

Figure 6. Histogram of specific percentage of quartz grains found in samples of the study area. 
Table 4. Percentage of different heavy minerals observed.

\begin{tabular}{|c|c|c|c|c|c|c|c|c|c|c|c|}
\hline \multirow{2}{*}{ Minerals (\%) } & \multicolumn{11}{|c|}{ Samples } \\
\hline & LM & ML & NY & $\mathrm{BL}$ & SB & WM & WB & BY & OD & TK & RG \\
\hline Opaque & 40 & 32 & 34 & 38 & 40 & 40 & 30 & 30 & 28 & 27 & 32 \\
\hline Zircon & 6 & 8 & 10 & 9 & 8 & 5 & 17 & 6 & 23 & 10 & 25 \\
\hline Green hornblende & 10 & 6 & 14 & 8 & 14 & 18 & 13 & 14 & 12 & 13 & 16 \\
\hline Brown hornblende & 2 & 5 & 7 & 5 & I & 6 & 3 & 2 & 4 & 3 & 3 \\
\hline Sillimanite & 8 & 6 & 10 & 9 & 9 & 8 & 5 & 8 & 7 & 12 & 12 \\
\hline Tourmaline & 12 & 5 & 7 & 5 & 6 & 7 & 8 & 9 & 11 & 10 & 12 \\
\hline Rutile & 8 & 2 & 5 & 3 & l & 1 & 2 & 2 & 3 & 4 & l \\
\hline Biotite & 6 & 15 & 8 & 12 & 15 & 12 & 8 & 13 & 4 & 11 & I \\
\hline Muscovite & 4 & 15 & I & 6 & 8 & I & 10 & 11 & 5 & 8 & l \\
\hline Sphene & I & 3 & I & I & I & 1 & 2 & 4 & 3 & I & I \\
\hline Glaucophane & I & 2 & & I & I & I & 1 & I & I & I & l \\
\hline Staurotide & 2 & I & 4 & I & I & 1 & 1 & 1 & I & I & I \\
\hline Garnet & I & 1 & 1 & 3 & l & 2 & 1 & I & l & I & I \\
\hline Hyperstene & 2 & l & l & 2 & I & l & l & I & l & 2 & l \\
\hline
\end{tabular}

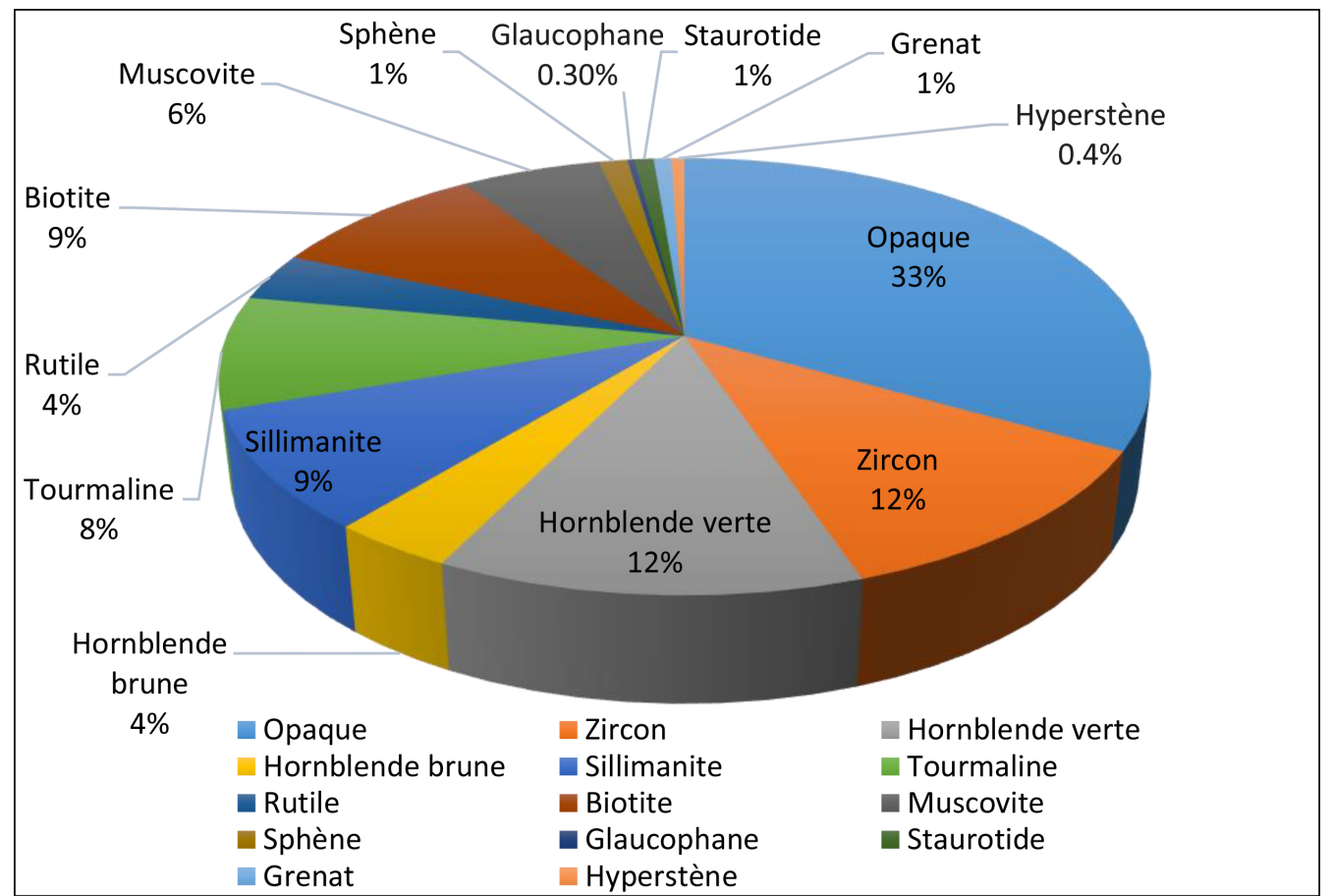

Figure 7. Circular diagram showing the distribution of heavy minerals. 
- Sillimanite is recognizable by its colorless appearance in PLNA and its lively $3^{\text {rd }}$ order shade in PLA. It has various forms. Its percentage in the samples varies between $5 \%$ and $12 \%$, for an average of $9 \%$.

- Biotite is brown with no extinction in the PLA. It has more or less elongated forms. Its percentage is between $2 \%$ and $15 \%$, with an average of $9 \%$. The $15 \%$ peaks are recorded in the ML and SB samples from the North West zone.

- The rutile is presented either in baguette with a clear outline or in rounded grain. It is brown to dark red in PLNA. It is no abundant in samples from the area and represents an average of $4 \%$ for all the minerals studied. Their percentage is between $1 \%$ and $8 \%$ with a peak found in the LM sample.

- Garnet in natural light is pink and globose with many cracks. Its percentage is between $1 \%$ and $3 \%$, for an average of $1 \%$.

- The staurotide is brown in natural light and has various forms. It is very weakly represented. Its average percentage is $1 \%$.

- Muscovite is colorless in PLNA; muscovite has pseudo hexagonal forms with cleavages. Its percentage ranges from $4 \%$ to $15 \%$, an average of $6 \%$ of all minerals. The $15 \%$ peak is recorded in the ML sample from the NWzone.

- The sphene is a colorless to yellow mineral with variable contours, showing cracks. It is also very little represented with an average of $1 \%$.

- Hypersthene shows a brown and greenish color in PLNA. Hypersthene has minerals that are blunt and more or less elongated. They are very poorly represented with an average percentage of $0.4 \%$.

- Glaucophane is white in polarized light not analyzed (PLNA) and dark blue in polarized light analyzed (PLA) with shapes that are more or less rounded. Its average percentage is also very low, around $0.3 \%$.

The rocks crossed by the rivers condition to a considerable degree of quality and quantity of the heavy minerals contained in the alluvium. Thus, it emerges from this study that the heavy minerals obtained come from two main mineralogical processions namely, the plutonic procession consisting of green hornblende, brown hornblende, sphene, hypersthene, tourmaline and a metamorphic procession consisting of sillimanite, glaucophane, and staurotide on the other hand. Biotite, garnet, muscovite, and zircon are so-called mixed minerals because of their occurrence in the two processions mentioned above the two mineralogical processions (plutonic and metamorphic) highlighted come from a single proximal distributing province. This confirms the existence in the area of several mineralize siliceous veins and veinlets and dissemination [5].

\subsubsection{Microcopy of the Polished Sections}

The polished sections of the bottom of the pits were observed at the GEMME Laboratory at the University of Liege in Belgium. The samples from four (04) sectors were the subject of this study namely; ML, RG, LM, and WB. The results of the observations are illustrated in the figures below and revealed the following: 
- The RG sample in natural and polarized light (Figure 8) reveals the presence of the following mineral species: Zircon (Zr), Garnet (Gr), Gold ( $\mathrm{Au}$ ), brown hornblende $(\mathrm{Hb})$, biotite $(\mathrm{Bt})$, and rutile $(\mathrm{Rt})$.

- The background sample ML shows the presence of Gold (Au), Zircon ( $\mathrm{Zr}$ ) and Sphene (Sp) (Figure 9).

- In the ML sample, the rutile (Rt) and augite (At) could be identified. The WB sample allowed the observation of gold metal and opaque minerals (Op) (Figure 10).

Although the sorting index (S0) shows well to fairly well-classified sediments, the rest of the parameters are the asymmetry coefficient (A), the Krumbein index (QdØ), the histograms and the cumulative curves show that the samples studied are generally poorly classified and poorly sorted sediments. They have a better ranking in the coarse fraction. From the particle size and morphoscopic point of view, the samples from the two sectors namely Lom (LM), Mali (ML), Nakoyo (NY), Bangbel (BL), Sarambi (SB), Boyo (BY), Tourake (TK), Wantamo (WM) in the North West zone and Woumbou (WB) Ouaden (OD) and Rigue (RG) in the South East zone are similar. The study of heavy minerals also shows that the samples from these two sectors are fed by plutonic and metamorphic processions. Note however the dominance of zircon in the samples from the SW zone in the Kadei watershed.
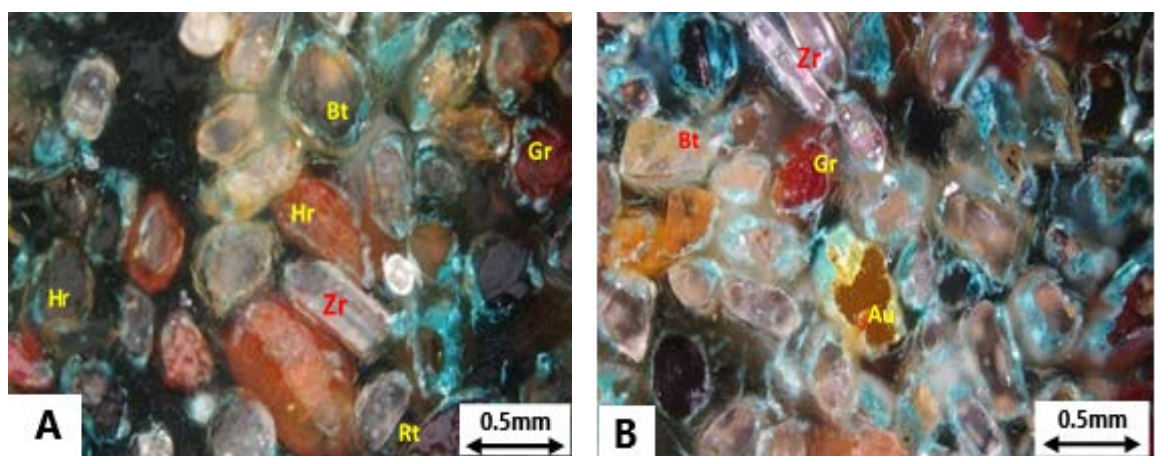

Figure 8. Polished sections of the bottom pan. (A), (B) Slide of the RG sample in natural ligh and polarize light respectively.

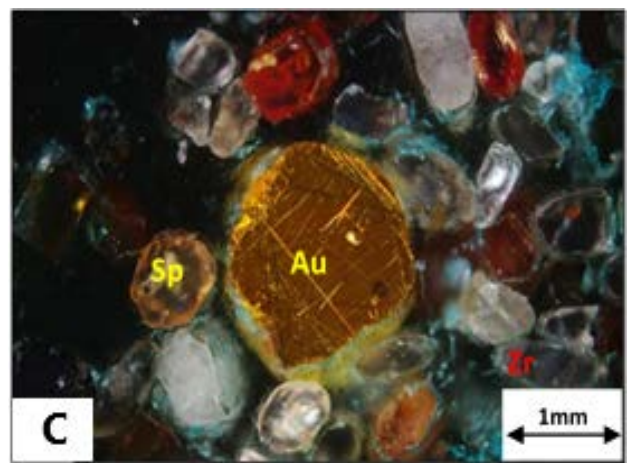

Figure 9. Polished sections of the bottom pan. (B) Thin section of the ML sample in polarized light. 


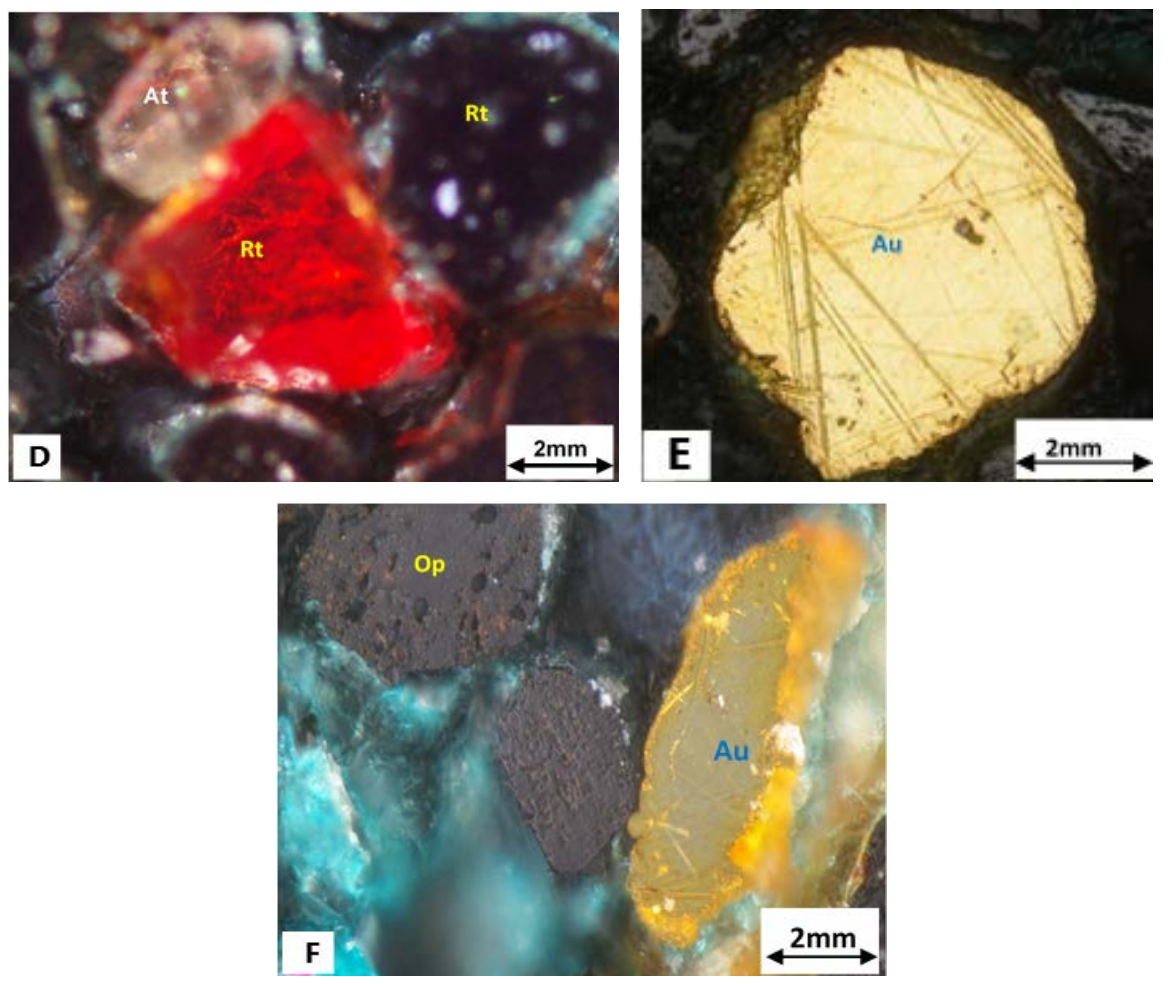

Figure 10. Polished sections of the bottom of the pan. (A) Thin section of the ML sample in natural light; (E) Slide of the LM sample in natural light; (F) Slide of the WB sample in natural light.

\section{Conclusions}

Alluvial deposits in the Bétaré-Oyaarea and its surroundings, in the eastern region of Cameroon notably in the sectors of: Lom, Mali, Nakoyo, Bangbel, Sarambi, Boyo, Wantamo, Tourake, Woumbou, Ouaden, and Rigue were the subject of a sedimentological study which relied notably on the particle size, morphoscopic analyzes and the study of heavy minerals. These analyzes made it possible to determine the origin and the conditions of installation of the sediments, to know the nature of their mineralogical content and their distribution in order to detect the zones of gold Mineralization. The results obtained showed the following: The alluvial deposits studied are sediments consisting of a coarse fraction, an abundant medium fraction and a fine fraction. The mean of the sorting index $S 0=2.53$ corresponds to sediments which are fairly classified overall. The QdØ values obtained are not close to zero (0), therefore, they are poorly classified sediments. The coefficient of asymmetry (A) which displays an average value of 0.73 , that is to say, less than 1 , reflects a maximum classification on the side of coarse grains; which would correspond to poorly-classified torrential sediments. Furthermore, the histograms constructed are on the whole plurimodal (bimodal to trimodal), which corresponds to deposits from a short course, by irregular currents, these are poorly-classified sediments. The frequency curves obtained do have weak and irregular slopes, they are poorly classified sediments. These sediments were deposited by current of strong compe- 
tence. These are likely torrential and/or fluvial deposits from short transport. Unused grains are dominant in almost all samples with an average of 80.5\%; which indicates short transport of sediments due to a proximal source. The rest of the grains are made up of shiny blunt (18.36\%) and round mast (1\%).

In terms of particle size and morphoscopy, the samples studied are poorly classified and poorly sorted sediments dominated by coarse fraction and mostly made of elements that are no worn. These sediments would be of fluvial and/or torrential origin from short course.

The heavy minerals revealed the presence of the following elements: zircons, sphene, green and brown hornblende, tourmaline, rutile, and hypersthene; sillimanite, staurotide, glaucophane, biotite, muscovite, garnet, gold, augite and opaque minerals. These minerals come from two proximal mineralogical processions, namely plutonic and metamorphic procession. The dominance of zircon in the Woumbou (WB), Rigue (RG) and Ouaden (OD) samples should be emphasized.

\section{Acknowledgements}

The authors are grateful for technical and material supports from the Gemme Laboratory of the University of Liege-Belgium; Laboratory of petroleum and sedimentary geology of the University of Yaounde I Cameroon. Thanks also to CAPAM/Minmidt, and Mipromalo Laboratories in Yaounde-Cameroon for their collaboration in this project.

\section{Conflicts of Interest}

The authors declare no conflicts of interest regarding the publication of this paper.

\section{References}

[1] Penaye, J. and Hell, J.V. (2013) Abandoned Artisanal Gold Mining Sites of Eastern Cameroon: Environmental Problems and Cameroon Regulation. Conférence Johannesburg.

[2] Soba, D. (1989) La série du Lom: Étude géologique et géochronologique d'un bassin volcano-sédimentaire de la chaîne panafricaine à l'Est du Cameroun. Thèse de doctorat d'Etat, Université Pierre et Marie Curie, Paris, 198 p.

[3] NihFon, A., BihChe, V. and CheoSuh, E. (2012) Application of Electrical Resistivity and Chargeability Data on a GIS Platform in Delineating Auriferous Structures in a Deeply Weathered Lateritic Terrain, Eastern Cameroon. International Journal of Geosciences, 3, 960-971. https://doi.org/10.4236/ijg.2012.325097

[4] Ngako, V., Affaton, P., Nnange, J.M. and Njanko, Th. (2003) Pan African Tectonic Evolution in Central and Southern Cameroon: Transpression and Transtension during Sinistral Shear Movements. Journal of African Earth Sciences, 36, 207-214. https://doi.org/10.1016/S0899-5362(03)00023-X

[5] Gazel, J. (1955) Notice explicative sur la feuille Batouri-Ouest. Direction des Mines. Cameroun, Yaounde, $44 \mathrm{p}$.

[6] Rivière, A. (1977) Méthodes granulo-métriques, techniques et interpretation. Mas- 
son, Paris, $170 \mathrm{p}$.

[7] Folk, R.L. and Ward, W.C. (1957) Brazos River Bar: A Study in the Significance of Grain Size Parameters. Journal of Sedimentary Petrology, 27, 3-26.

https://doi.org/10.1306/74D70646-2B21-11D7-8648000102C1865D

[8] Pinot, J.P. (1933) Rapport surl'évolution du littoral autour de la baie de Lannion et sur la cote de Granite Rose. Rapport présenté pour le SMVW, Université de Bretagne Occidentale, $115 \mathrm{p}$.

[9] Visher, G.S. (1969) Grain Size Distributions and Depositional Processes. Journal of Sedimentary Petrology, 39, 1074-1106. https://doi.org/10.1306/74D71D9D-2B21-11D7-8648000102C1865D

[10] Moiola, R.J. and Weiser, D. (1968) Textural Parameters: An Évaluation. Journal of Sedimentology and Petrology, 38, 45-53.

[11] N’Guessan, Y.L., Amani, E.M., Koffi Bi, K.F., Adopo, L., Diangone Bi, E., Monde, S. and Kouadio, A. (2014) Caractérisation morphologique et sédimentologique de l'embouchure du fleuve Sassandra (Côte d'Ivoire). Afrique Science, 10, 277-288.

[12] Ondo, N., Makaya, M. and Mouyalou, M.T. (2018) Caractérisation sédimentologique des sables superficiels de la zone côtière gabonaise dans le secteur de Setté-Cama. Agronomy, Earth and life Sciences REV. RAMRES, 6, 73-79.

[13] Cailleux, A. and Tricart, J. (1959) Initiation à l'étude des sables et des galets. Centre de Doc. Univ., Paris.

[14] Gentile, W. (1992) (b) Minéralogie et morphoscopie des sables. 103 p.

[15] Alali, A., Benmohammadi, A. and Boudadl, A. (2014) Etude Sedimentologique Des Sables Dunaires De La Plaine De Tafilalet (Yerdi, Labrouj, Mfis, Merzouga et Lambarkia). Larhyss Journal, 17, 155-177.

[16] Berthois et Lucas (1975) Etude Sédimentologique des Roches Meubles. Doin, Paris, $278 \mathrm{p}$.

[17] Parfenoff, A., Pomerol, C. and Tourenq, J. (1970) Les minéraux en Grains, méthodes d'étude et détermination. Masson et Cie, Editeurs. 120, Boulevard saint-Germain, Paris $\left(6^{\mathrm{e}}\right), 550 \mathrm{p}$.

[18] Bachelier, G. (1963) Utilisation de certaines matières plastiques en pédologie (inclusion, sections polies, lames minces, profils collés). Bulletin bibliographique de pédologie. Tom XII, fascicule 4, ORSTOM.

[19] Nevado, C. (2002) La préparation d'échantillon de roche pour l'analyse EBSD. Université de Mompellier II.

[20] Pomerol, C. and Blondeau, A. (1968) Initiation à la géologie pratique. Edition N. Boubee et CIR 3, place saint-André-des Arts, paris VI, 217 p. 